\title{
Ataxia teleangiectasia. Az idegrendszeri érintettség prototípusa primer immundefektusokban
}

\author{
Liptai Zoltán dr. \\ Dél-pesti Centrumkórház - Országos Hematológiai és Infektológiai Intézet, \\ Szent László Kórház Telephely, Budapest
}

\begin{abstract}
A veleszületett immundefektusok száma meghaladja a 350-et, és körülbelül egynegyedüknek vannak neurológiai vonatkozásai. Még nagyobb hányadukban fordulhatnak elő súlyos központi idegrendszeri infekciók. Az idegrendszeri vonatkozású kórképek táblázatos összefoglalása mellett a szerző részletesen elemez egy jellegzetes betegséget. Az ataxia teleangiectasia oka az ATM-gén biallélikus mutációja, amely genomikus instabilitáshoz, fokozott tumorrizikóhoz, immundefektushoz, valamint elsősorban kisagyi neurodegenerációhoz vezet. A leggyakoribb, klasszikus kórformát törzs- és végtagataxia, oculomotoros apraxia, choreoathetosis, ritkán egyéb mozgászavar, beszéd- és nyelészavar jellemzi, jelentősebb kognitív deficit nincs. Teleangiectasiák a conjunctivákon és a bőrön általában 6 éves kor után jelennek meg. Gyakori infekciók jelezhetik a betegek 60-80\%-ában előforduló immundefektust, melyre elsősorban súlyos sinopulmonalis infekciók hívják fel a figyelmet. A betegek hajlamosak malignus betegségekre. A kórlefolyás néha atípusos és/vagy késői kezdetű, ami megnehezíti a diagnózis megállapítását. A betegek szérumában majdnem mindig emelkedett az alfa-fetoprotein-szint, a koponya-MRI-n 7-8 éves kortól progresszív cerebellaris atrophia figyelhető meg. A kórisméhez az ATM-gén vizsgálata szükséges; a talált biallélikus patogénmutációk segítséget nyújtanak a családtervezésben, de esetleges jövóbeli génterápiának is az alapját képezik. Az ataxia teleangiectasia számos betegségtől különítendő el, melyek egy része ugyancsak a primer immundeficientiák közé tartozik. Oki terápia jelenleg nincs, a betegek a legtöbbször fiatal felnőtt korukig élnek.
\end{abstract}

Orv Hetil. 2018; 159(49): 2057-2064.

Kulcsszavak: ataxia teleangiectasia, ATM-gén, immundeficientia, kisagy

\section{Ataxia telangiectasia. A prototype of neurological involvement in primary immune deficiencies}

The number of primary immune deficiencies exceeds 350, approximately a quarter of them having neurological implications. Severe central nervous system infections may occur in an even higher proportion. Beyond listing in a table of all diseases with a neurological impact, the author gives detailed analysis of one typical disorder. Ataxia telangiectasia is caused by biallelic mutation of the ATM gene resulting in genomic instability, increased cancer risk, immune deficiency and a predominantly cerebellar neurodegeneration. The most common classic form is characterized by gait and limb ataxia, oculomotor apraxia, choreoathetosis, disturbance of speech and swallowing, less often by other movement disorders. There is no remarkable cognitive deficit. Telangiectasia of the conjunctivae and skin usually appears after 6 years of age. Frequent, especially severe sino-pulmonary infections may indicate the immune deficiency present in 60 to $80 \%$ of patients, who are also prone to malignancies. The clinical course is sometimes atypical or has a late onset which results in diagnostic difficulties. Serum alpha-fetoprotein level is elevated in nearly all patients. Brain MRI shows progressive cerebellar atrophy starting at the age of $7-8$ years. DNA testing of the ATM gene is necessary for the diagnosis. The detected biallelic pathogenic variants provide help for family planning and for possible gene therapies in the future. Ataxia telangiectasia has to be differentiated from a number of other disorders, some of which also belong to primary immune deficiencies. The disorder has no causal treatment at present, the patients live until their young adult ages.

Keywords: ataxia telangiectasia, ATM gene, immunodeficiency, cerebellum

Liptai Z. [Ataxia telangiectasia. A prototype of neurological involvement in primary immune deficiencies]. Orv Hetil. 2018; 159(49): 2057-2064.

(Beérkezett: 2018. augusztus 6.; elfogadva: 2018. szeptember 16.) 


\section{Rövidítések}

$\mathrm{AFP}=$ alfa-fetoprotein $; \mathrm{AMO}=$ antisense morpholino oligonukleotidok; $\mathrm{AOAl}=$ ataxia-oculomotoros apraxia 1 -es típusa; AOA2 = ataxia-oculomotoros apraxia 2 -es típusa $;$ AT = ataxia teleangiectasia; ATLD = ataxia teleangiectasia-szerü betegség; $\mathrm{ATM}=($ ataxia telangiectasia mutated $) ; \mathrm{CT}=($ computed tomography) számítógépes tomográfia; DNS = dezoxiribonukleinsav; Ig = immunglobulin; ILD = (interstitial lung disease) interstitialis tüdőbetegség; IOSCA = (infantile-onset spinocerebellar ataxia) csecsemókori kezdetű spinocerebellaris ataxia; IUIS $=($ International Union of Immunological Societies $)$ Immunológiai Társaságok Nemzetközi Szövetsége; MCSZ = (microcephaly, seizures, developmental delay) microcephalia, görcsök, vontatott fejlődés; MRI = (magnetic resonance imaging) mágnesesrezonancia-képalkotás; NBS = (Nijmegen breakage syndrome) Nijmegen-törés-szindróma; NGS = (next generation sequencing) új generációs szekvenálás; $\mathrm{PEG}=$ (percutaneous endoscopic gastrostomy) perkután endoszkópos gastrostoma; $\mathrm{PET}=$ (positron emission tomography) pozitronemissziós tomográfa; SANDO = (sensory ataxic neuropathy, dysarthria and ophthalmoplegia) szenzoros ataxiás neuropathia dysarthriával és ophthalmoplegiával; se = szérum; WES = (whole-exome sequencing) teljesexom-szekvenálás; XCIND = X-ray sensitivity, cancer, immunodeficiency, neuropathology, DNA repair deficiency

A ma ismert veleszületett immundefektusok száma meghaladja a 350-et, melyek 344 gén mutációival kapcsolatosak (2017. évi adat [1]). Az Immunológiai Társaságok
Nemzetközi Szövetsége (International Union of Immunological Societies, IUIS) rendszeres időközönként megújítja, bővíti e betegségek fenotípus szerinti klasszifikációját, illetve listáját. Az utolsó szisztematikus jegyzék 2018 elején jelent meg [2]. A kórképek többsége monogénes, a leggyakrabban autoszomális recesszív (AR) öröklődésü [1].

E betegségek kb. egynegyedének vannak nem infekciós vagy specifikus infekciós (az egyes kórokozók elleni védekezés zavara) neurológiai vonatkozásai, melyek részletes ismertetése meghaladja e közlemény kereteit, ezért az idetartozó kórképeket a legfrissebb IUIS-osztályozás szerint táblázatban foglaltam össze (1. táblázat). Jóval több esetben fordulnak elő súlyos, a központi idegrendszert (is) érintő, gyakran opportunista kórokozók okozta infekciók (1. és 2. ábra) az immunhiány következtében. Az idegrendszer mellett többnyire más szervek is érintettek, sokszor vannak jelen dysmorphiás jegyek, ami segítheti a diagnosztikát. Gyakoriak az agyi struktúrák, a retina fejlődési zavarai, microcephalia [3], migrációs zavarok, corpus callosum hypo- vagy agenesia, néha agyi meszesedés, sensorineuralis halláscsökkenés [4], a központi idegrendszert (is) érintő fokozott hajlam malignitásokra. Ezen fejlődési rendellenességek mellett vagy ezek hiányában is sokszor észlelhető meglassult motoros és/vagy kognitív fejlődés, akár súlyos pszichomotoros retardáció, hypotonia, görcsök, ataxia, stroke, de előfordul visszatérő encephalopathia [5] (3. ábra),

1. táblázat | Neurológiai vonatkozású kórképek az IUIS (Immunológiai Társaságok Nemzetközi Szövetsége) legfrissebb klasszifikációja szerinti csoportosításban

\begin{tabular}{|c|c|}
\hline Csoport & Neurológiai érintettséggel járó kórképek \\
\hline $\begin{array}{l}\text { I. A cellularis ÉS a humoralis immu- } \\
\text { nitás zavarai (súlyos és kevésbé sú- } \\
\text { lyos kombinált immundefektusok) }\end{array}$ & $\begin{array}{l}\text { Winged helix deficientia, adenozin-deamináz-defektus, reticularis dysgenesis, LIG4-szindróma, Cernun- } \\
\text { nos/XLF deficientia, DNS-PKcs-deficientia, BCL11B-deficientia }\end{array}$ \\
\hline $\begin{array}{l}\text { II. Kombinált immundefektusok } \\
\text { társult tünetekkel vagy szindróma } \\
\text { formájában }\end{array}$ & $\begin{array}{l}\text { Ataxia teleangiectasia, Nijmegen-törés-szindróma (NBS), PMS2-defektus, RNF168-defektus, polimeráz- } \\
\text { e-alegység-deficientia-1, ERCC6L2 (Hebo)-deficientia, porc-haj hypoplasia, MOPD1-deficientia, EXTL3- } \\
\text { deficientia, Di George- (22q11.2 deletio) szindróma, CHARGE-szindróma, PGM3-deficientia, dyskerato- } \\
\text { sis congenita, COATS plusz szindróma, SAMD9L-asszociált ataxia-pancytopenia szindróma, transz-koba- } \\
\text { lamin-2-deficientia, örökletes folsavmalabszorpció, metilén-tetrahidrofolát-dehidrogenáz-1-deficientia, } \\
\text { purin-nukleozid-foszforiláz-defektus, hepaticus venoocclusiv betegség immundeficientiával (VODI), Vici- } \\
\text { szindróma, kalciumcsatorna-defektusok, Kabuki-szindróma }\end{array}$ \\
\hline
\end{tabular}

III. Dominálóan antitesthiánnyal PTEN-deficientia, mannozil-oligoszacharid-glükozidáz-deficientia, szelektív IgM-hiány járó betegségek

\begin{tabular}{ll}
\hline IV. Immundiszregulációs zavarok & Chédiak-Higashi-szindróma, Hermansky-Pudlak-szindróma 10-es típusa, FADD-deficientia \\
\hline $\begin{array}{l}\text { V. Phagocyták hiánya, illetve mükö- } \\
\text { dészavara }\end{array}$ & GPC3-deficientia, Cohen-szindróma, Barth-szindróma, Clericuzio-szindróma, 3-metilglutakonsav-aci- \\
& duria, Kostmann-szindróma, -aktin-asszociált betegségek, fehérvérsejt-adhaesiós defektus II-es típusa \\
& (LADII), krónikus granulomatosis (CGD)
\end{tabular}

VI. Az intrinszik és veleszületett im- A bacterialis, mycobacterialis, vírus-, gomba- és parazitafertőzések elleni specifikus védekezés zavarai, osteomunitás zavarai petrosis, akut nekrotizáló encephalopathia

VII. Autoinflammatiós szindrómák Muckle-Wells-szindróma, újszülöttkori kezdetú multiszisztémás gyulladásos betegség (NOMID) vagy krónikus csecsemőkori neurológiai, bőr- és ízületi tünetegyüttes (CINCA), PAPA-szindróma, Blau-szindróma, otulipenia, l-es típusú interferonopathiák: Aicardi-Goutières-szindróma, spondyloenchondrodysplasia immundiszregulációval, ADA2-deficientia, USP18-deficientia

VIII. Komplementhiány Szisztémás Neisseria-fertőzéshez vezető génhibák (C5-, C6-, C7-, C8-, C9-deficientia), a komplementfaktor B zavarai, a faktor $\mathrm{H}$ hiánya, a faktor $\mathrm{H}$-asszociált fehérjék hiánya, faktor I-deficientia, membránkofaktorfehérje-hiány, membrán attack komplex inhibitor hiány

IX. A primer immundeficientia Cryopyrinopathia (Muckle-Wells/CINCA/NOMID-szerü szindróma), pulmonalis alveolaris proteinosis fenokópiái 


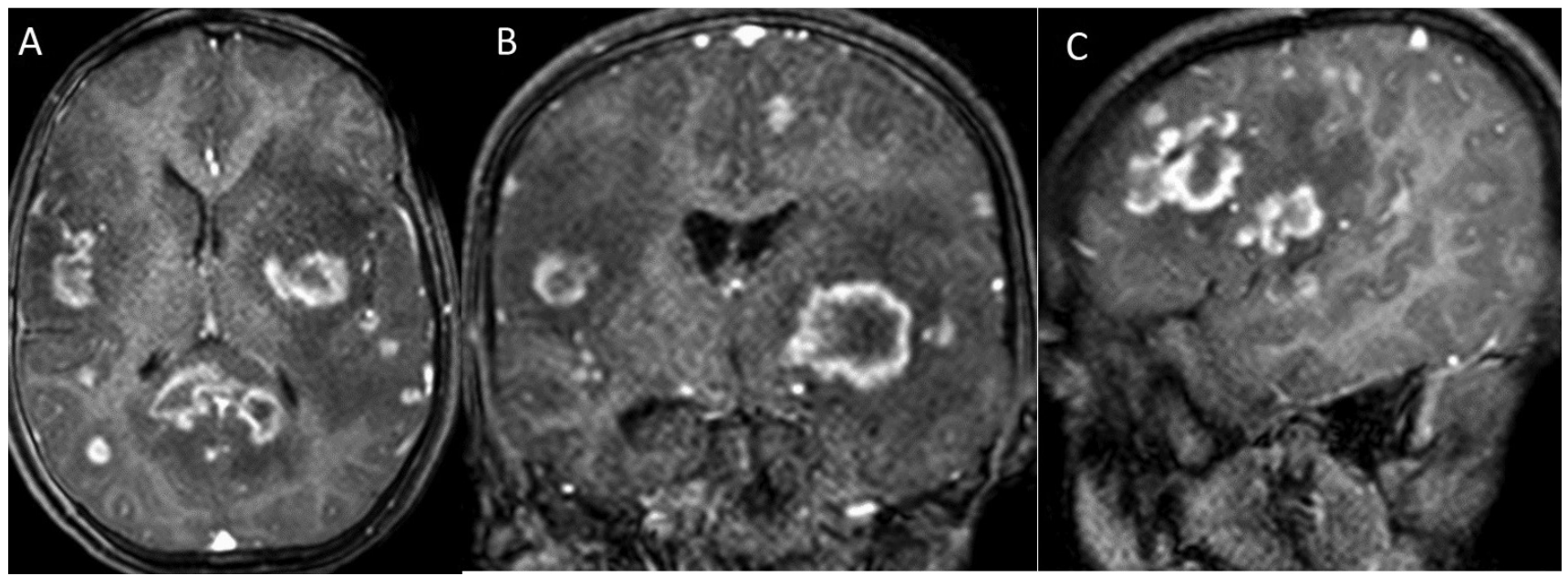

1. ábra

DOCK8-deficientiában szenvedő 10 éves leány kontrasztanyagos axialis (A), coronalis (B) és sagittalis síkú (C), T1-súlyozott koponya-MR-felvétele. Az alapbetegség hátterében a DOCK8-gén homozigóta, nagy deletiója állt, a láztalanul, lassan kibontakozó idegrendszeri gyulladást Toxoplasma gondii okozta. Mindhárom képen látható a többszörös gócok széli kontrasztanyag-halmozása, a nagyobb gócok körüli, csökkent jelú perifokális ödéma, mely az axialis síkú felvételen (A) komprimálja a bal frontalis kamraszarvat, a coronalis képen pedig jól láthatóan diszlokálja a középvonalat

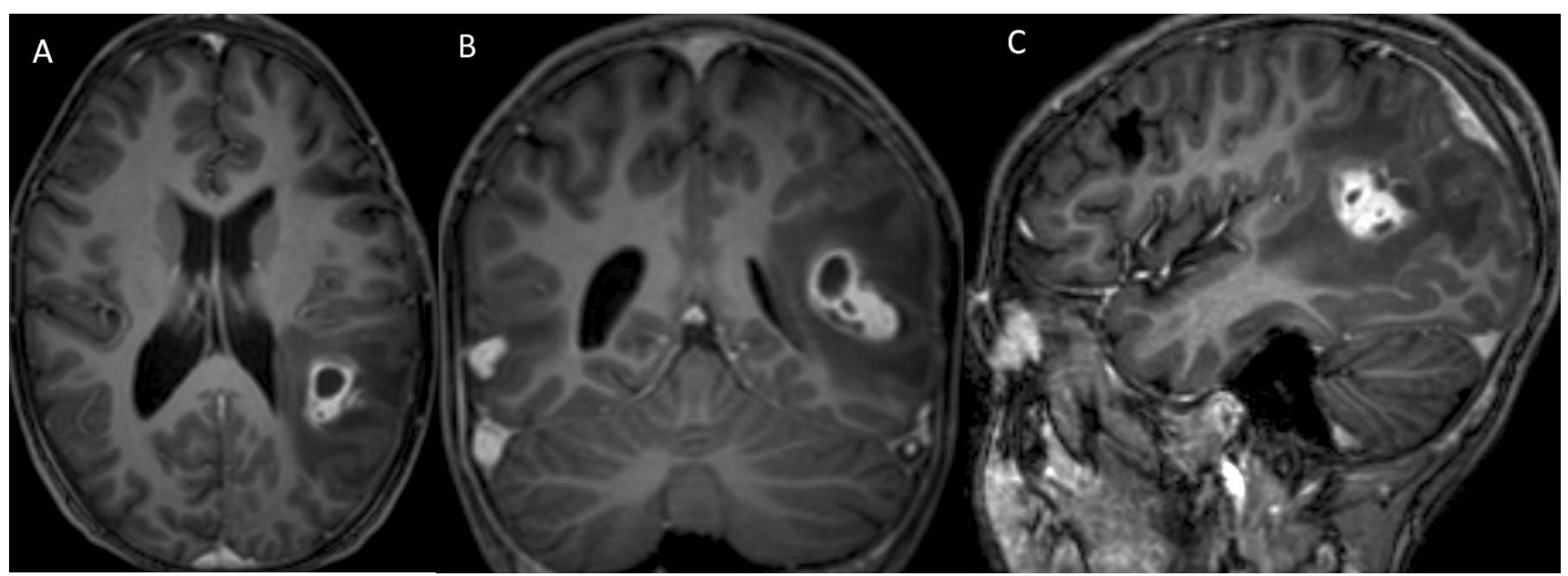

2. ábra

18 éves, X-hez kötött (édesanyjánál 40 éves kor után jelentkeztek enyhe tünetek) krónikus granulomatosisban (CGD) szenvedő fiú multiplex agytályogja. Az axialis (A), coronalis (B) és sagittalis (C), kontrasztanyagos Tl-súlyozott MR-felvételeken többrekeszes, széli részein intenzíven halmozó abscessus látható a bal oldali parietooccipitalis régióban és egy kicsiny elváltozás a jobb parietalis régióban. A kórokozóra kiterjesztett mikrobiológiai vizsgálatok ellenére nem derült fény. A folyamat hosszan tartó, kombinált antibakteriális és antifungális, valamint szteroidkezelés mellett gyógyult

agyidegi és polyneuropathia, myalgia, myositis is. Ha mindezek meglassult vagy stagnáló szomatikus fejlődéssel, visszatérố és/vagy opportunista infekciókkal társulnak, okkal merül fel veleszületett immundeficientia gyanúja. Egyes betegségek lezajlása központi idegrendszeri infekcióra emlékeztet, de nem infektív ágens okozza (például Aicardi-Goutières-szindróma [6]).

A továbbiakban egy jellegzetes, klasszikus betegségről, az ataxia teleangiectasiáról lesz szó mint a neurológiai érintettséggel is járó veleszületett immundeficientiák prototípusáról.

\section{Ataxia teleangiectasia (AT)}

Az AT - első leírója után Louis-Bar-szindróma - az IUIS-felosztás II. fócsoportjának (kombinált immunde- ficientia társult tünetekkel vagy szindróma formájában) egyéb DNS-repair-defektusok alcsoportjába tartozik.

Incidenciája l : 40 000-1 : 100000 újszülött [7], prevalenciája 1-9 : 100000 [8]; függ az adott populációban a rokonházasságok gyakoriságától. A leggyakoribb gyermekkori progresszív cerebellaris ataxia [7].

Genetikai alapja a 11-es kromoszóma hosszú karjára lokalizálódó, 62 kódoló exonnal rendelkező ATM(ataxia telangiectasia mutated) gén biallélikus (homozigóta vagy compound heterozigóta) patogén mutációja. Bár a founder effektusnak megfelelően egyes populációkban bizonyos variáns gyakoribb lehet, nincs a génnek olyan része, mely különösen hajlamos lenne mutációra: a proximalis, centrális és distalis szakaszok egyaránt érintettek lehetnek [8]. Több mint 800 patogén variáns ismert, és a legtöbb beteg compound heterozigóta [8]. Főleg (az esetek körülbelül 90\%-ában) nonsense pont- 


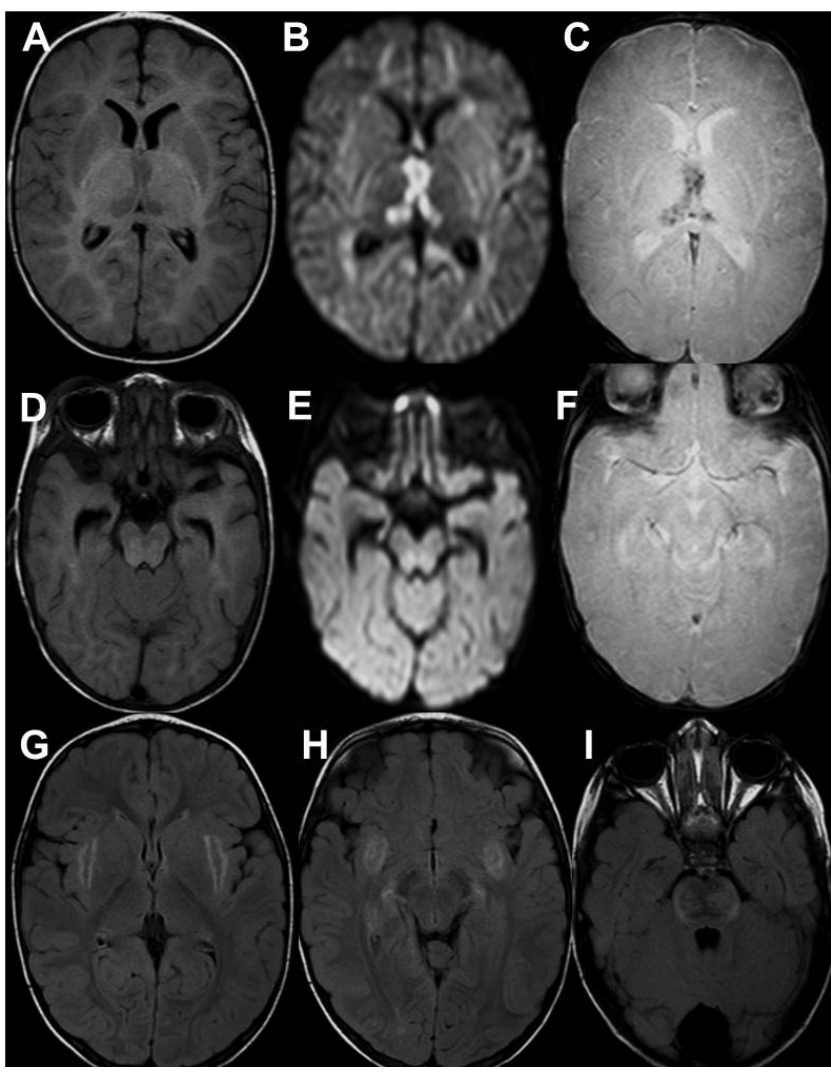

3. ábra

\begin{abstract}
5 hónapos, autoszomális domináns akut nekrotizáló encephalopathiában (ANE1) szenvedő kisfiú koponya-MR-felvétele. Axialis FLAIR-felvételen (A) a thalamusok duzzadtak, belső rétegük csökkent, a külső fokozott jelet ad. A belső rétegben gátolt a diffúzió (B), az FFE-T2-felvételen (C) pedig mikrovérzéseknek megfelelő, apró jelszegény területek (fekete pontok) láthatók. Axialis FLAIR-képen fokozott jelű gócok láthatók a mesencephalonban is (D), gátolt diffúzióval (E), de az FFE-T2-szekvencián (F) itt vérzés nincs. A 2,5 éves korában zajlott második epizódja alkalmával axialis FLAIR-felvételen érintett mindkét oldalon a capsula externa és a claustrum $(\mathrm{G})$, az insula és a temporomedialis struktúrák; az amygdalák és a hippocampusok $(\mathrm{H})$, a corpus mamillarék (nem látszik), valamint a pons lateralis részei (I). A gyermeknél a RANBP2-gén szekvenálása során heterozigóta c.1966A $>\mathrm{G}$ patogén mutáció igazolódott. Az anyai féltestvér és az anya ugyancsak hordozza a variánst: az előbbinél egy hasonló klinikoradiológiai epizód zajlott le, az utóbbi egészséges
\end{abstract}

mutációk, valamint deletiók, insertiók okozta olvasási kereteltolódások (frame-shift) jellemzők, de előfordul missense és splice-site mutáció is. A mutációk zöme tehát csonkoló, azaz instabil proteinfragmentumok keletkeznek. A betegség klasszikus fenotípusában a funkcionális ATM-fehérje nem mutatható ki [8].

\section{Patomechanizmus}

Az ATM-gén kódolja az ATM-fehérjét, mely 3056 aminosavból álló szerin/treonin kináz: többféle szubsztrátot foszforilál és regulál. Fóleg a sejtmagban, kisebb mennyiségben a citoplazmában, a mitokondriumokban és a peroxiszómákban van jelen. Termelődését oxidatív stressz, hypoxia, hypotoniás stressz, hyperthermia, a ket- tős szálú DNS törései aktiválják. Hiányában oxidatív, irradiációs és egyéb genotoxikus stressz hatására a DNS károsodik, genominstabilitás jön létre, amely elsősorban kisagyi neurodegenerációhoz, valamint daganatképződéshez vezet. Jelentős a Purkinje-, kisebb léptékû a granularis sejtek vesztése, aminek nyomán a kisagyi vermis és a hemisphaeriumok diffúz, progresszív degenerációja, atrophiája alakul ki. Csökevényes a thymus $[7,8]$.

\section{Klinikai kép}

A leggyakoribb (a betegek legalább kétharmadát érintő), klasszikus kórforma vezető tünetei a következők $[7,8]$ :

- Járási, illetve törzsataxia, mely 1-4 éves korban, nem sokkal az önálló járás kialakulása után kezdődik: a gyermek imbolyogni, tántorogni kezd. Az életkori fejlődés okán 2-4 éves korban még úgy tünik, hogy az állapot javuló, körülbelül 10 éves kortól azonban a legtöbben elvesztik járóképességüket.

- Végtagataxia: néhány év múlva, körülbelül 5 éves kor után a végtagok is érintetté válnak: az írás, rajzolás, színezés, evőeszköz-használat nehezítetté válik.

- Oculomotoros apraxia: nagyon jellemző, minden esetben kialakul; a beteg képtelen egy mozgó tárgyat a szemével követni. Mind a vertikális, mind a horizontális síkban való szemmozgás nehezített. Mindez a fej kompenzáló ingásához vezet, megnehezíti az olvasást, és átmeneti kinetosisszerü panaszokat, visszatérő hányásokat is okozhat.

- Progresszí dysarthria, elmosódott beszéd már korán jelentkezik.

- Nyelészavar, rágási nehézség, melyek hosszú távon alultápláltsághoz, a növekedés leállásához vezethetnek.

- Nyálzás: gyakori.

- Choreoathetosis előbb-utóbb minden esetben kialakul.

- Myoclonus, intenciós tremor a betegek egynegyedében fordul elő.

- Ballisztikus, retropulzív vagy rángásszerü mozgások inkább felnőttkorban alakulhatnak ki.

- Dystonia, törzshypokinesis, bradykinesis, szegényes arcmimika: ritka.

- Az izomerō kezdetben normális, de késóbb, az immobilitás miatt, fooleg az alsó végtagokon csökken.

- Később kontraktúrák alakulhatnak ki, főleg a kézujjakon: gyulladásos kötőszöveti betegség vagy polyneuropathia részeként.

- Scoliosis: ritka.

- A mélyreflexek renyhék vagy kiestek, ugyanakkor talpreflexre többnyire dorsalflexio (Babinski-jel) vagy néma talp a válasz. Felnőttkorra progresszív szenzoros és motoros polyneuropathia is kialakulhat, a lábfejek deformitásával.

- Tanulási nehézség (elsősorban az időtartam megítélésének zavara, más kognitív funkciók, például a nonverbális memória, verbális absztrakt érvelés, számolás, egzekutív funkciók zavara): gyakori, bár az intelligen- 


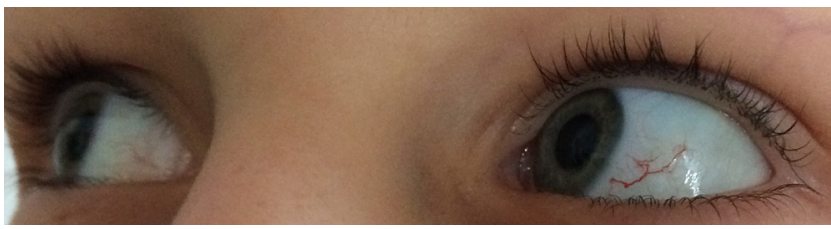

4. ábra

Ataxia teleangiectasiás, 9 éves leány mindkét, de fóleg a bal conjunctiváján látható teleangiectasia. A kivizsgálást enyhe tanulás nehézségek, mozgáskoordinációs zavar indokolták (a szülők engedélyével)

cia általában normális. Megítélését azonban a lassú motoros és verbális tempó nehezíti.

- Teleangiectasiák a conjunctivákon és a börön, olykor a belső szervekben (húgyhólyag, agy, máj, tüdő) általában 6 éves kor után jelennek meg (4. ábra), néha azonban később sem alakulnak ki, hiányuk tehát nem zárja ki az AT-t.

- Gyakori infekciók jelezhetik a betegek 60-80\%-ában előforduló humoralis és cellularis, az esetek többségében nem progresszív immundefektust, annak mértékével azonban nem feltétlenül korrelálnak. Különösen jellemzők a sinopulmonalis infekciók, és az esetek több mint negyedében krónikus tüdőérintettség, bronchiectasia, tüdőfibrosis, interstitialis tüdőbetegség (ILD) alakul ki, melyek sokszor a beteg halálához vezetnek. Opportunista kórokozók által okozott fertôzések nem jellemzők. Fokozott a betegek hajlama autoimmunitásra (thrombopenia, arthritis, vitiligo) is. Az immunhiány leggyakoribb indikátora a pneumococcus elleni oltásra adott szerény ellenanyagválasz [9], de előfordul egy-egy immunglobulinosztály vagy -alosztály (különösen az IgA, IgE és IgG2) szintjének csökkenése, néha emelkedett se-IgM-szinttel, valamint fóleg a T-sejteket érintő - lymphopenia. A betegek $<10 \%$-ában a bőrön krónikus granulomák alakulhatnak ki.

- Ionizáló sugárzásra való fokozott érzékenység és malignitásra (általában leukaemia vagy lymphoma, felnőttekben ezek mellett emlő-, máj-, gyomor-, oesophagus-, ovariumcarcinoma, melanoma, sarcomák) való bajlam jellemző.

- Korai öregedés, öszülés.

- Endokrinológiai zavarok, például glükózintolerancia, inzulinrezisztens diabetes mellitus, korai ovarialis insufficientia.

- Kialakulhat a máj zsíros degenerációja, cirrbosis.

- Osteoporosis/osteopenia, alacsony D-vitamin-szint.

- Gastrooesophagealis reflux.

- Depresszió.

A legtöbb neurológiai tünet progressziója 12-15 éves korban leáll [4].

A bevezető tünetek egy család érintett tagjaiban nagyon különbözők lehetnek, az előrehaladott stádium sokkal inkább hasonló [7].

A részletezett klasszikus („tipusos”, „korai kezdetu””, „gyermekkori kezdetu””) kórforma mellett a betegek kis részében enyhébb („atipusos”, „variáns”, „késôi kezdetü”, „felnöttkori kezdetu"”) klinikai megjelenés nehezítheti meg a kórismézést. A tünetek kevésbé súlyosak, a túlélés hosszabb, olykor nem ataxia az első tünet, hanem myoclonus, dystonia, choreoathetosis vagy tremor. Nem jellemző a tüdőérintettség, és ritkább az immundeficientia. Malignitás (többnyire nem vérképző szervi) kialakulása sokszor megelőzi az AT diagnózisának megállapítását [7, 8]. A következő atípusos AT-kórformákat írták le:

- $A T_{\text {Fresno }}$ : a klasszikus AT és a Nijmegen-törés-szindróma tüneteit (arcdysmorphia, progresszív microcephalia, a növekedés elmaradása, vontatott pszichomotoros és beszédfejlődés, iskoláskorban kognitív regresszió) egyaránt mutatja [10].

- Korai kezdetü dystonia vagy hypotonia, mennonita családokban, magas tumorgyakorisággal, kemoterápiára adott adverz reakciókkal, legalább az egyik ATM-allélon c.6200C >A variánssal.

- Progresszín dystonia [11].

- Levodopareszponzív nyaki dystonia és conjunctiva teleangiectasia: igen ritka, az ATM-gén meghatározott variánsai okozzák [12].

- Felnöttkori kezdetü spinalis izomatrophia [13].

- Mammacarcinoma, melyet késői kezdetü AT követ: mindössze két családban írták le eddig [14].

- Heterozigóták, bár többnyire egészségesek, a tumorrizikójuk (mamma és gyomor-bél rendszeri) körülbelül $4 \times$-es [15], és magasabb a coronariabetegség kockázata [7]; várható élettartamuk kissé alacsonyabb [8].

Diagnózis: ha az AT a tünetek alapján felmerül, az alábbi kiegészítő vizsgálatok segítségével juthatunk el a kórisméig:

- Az alfa-fetoprotein (AFP) az AT-betegek 95\%-ában 2 éves kor után ismeretlen okból megemelkedik, akár a normális felső határának 50-100-szorosára. Értéke nem korrelál a kisagykárosodás mértékével, prognosztikai szerepe sincs $[7,8]$.

- Magasabbak lehetnek a májtranszaminázok, a szérumkoleszterin és-triglicerid-szint.

- Jellemző a - föleg a T-sejteket érintő - lymphopenia és az alacsony immunglobulinszintek: elsösorban az $\operatorname{IgA}$, IgG, IgG-alosztályok és az IgE.

- Rutin-kromoszómavizsgálat során a sejtek 5-15\%ában mutatható ki 7;14 transzlokáció.

- Fokozott a kromoszómák spontán és indukált törékenysége.

- Csökkent a tenyésztett lymphocyták és a fibroblastok túlélése ionizáló sugárzás hatására.

- A koponya-MRI a betegség kezdetén normális lehet [8], a klinikai progresszióval azonban megjelennek az alábbi eltérések:

- Progresszí és diffúz cerebellaris atrophia, melynek hátterében a Purkinje- és a szemcsés sejtek depletiója áll, és legkésőbb 7-8 éves korra kialakul. Az elülső és hátsó vermis, valamint a féltekék atrophiája is megfigyelhető (5. ábra). 


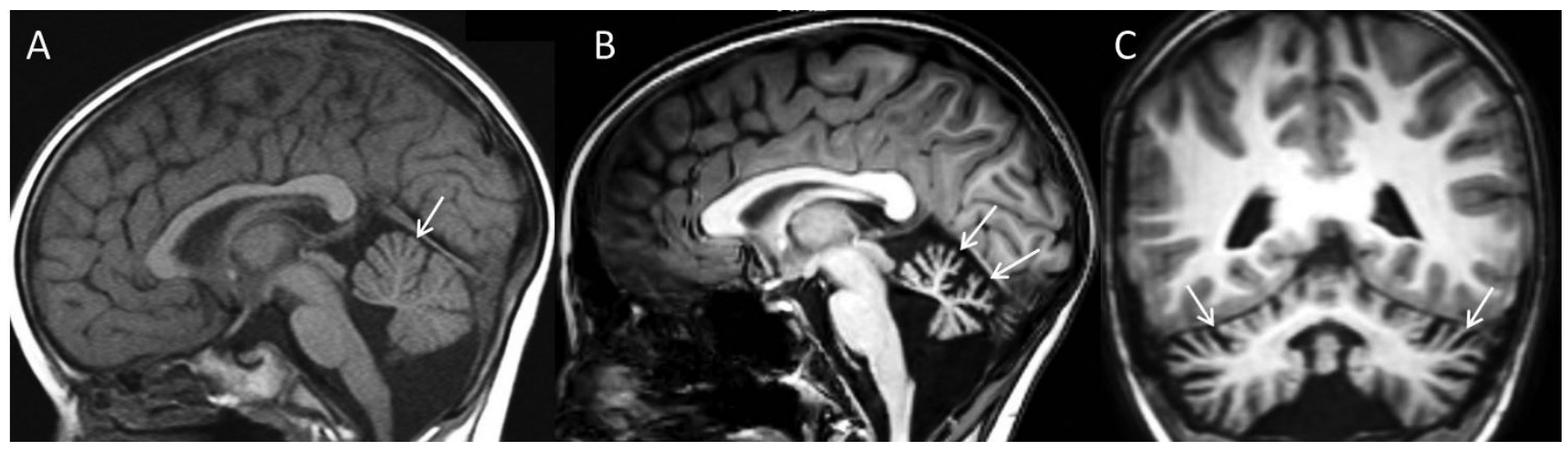

5. ábra

A 4. ábrán látható ataxia teleangiectasiás leány T1-súlyozott MR-felvétele 2,5 (A), illetve 9,5 éves korban (B, C). 2,5 éves korban sagittalis képen fóleg a felső vermis atrophiája látható (A), mely 9,5 éves korra jelentősen előrehaladt (B), sőt a coronalis képen (C) a cerebellaris hemisphaeriumok sorvadása is megfigyelhető. Az AFP $353,1 \mathrm{ng} / \mathrm{ml}$ (ref. <10) volt, a genotoxikológiai vizsgálat fokozott spontán és indukált kromoszómatörékenységet mutatott. Az ATM-gén szekvenálása során az egyik allélon c.7189C>T nonsense, a másikon c.2376G>T missense, ismert patogénmutáció volt azonosítható (a szülók vizsgálata alapján) transz-helyzetben

- Extracerebellaris, nagyagyi fehérállományi eltérések is lehetségesek, például hemosziderindepozitumok, mély cerebralis teleangiectasiák, degeneratív elváltozások a cerebellumból jövő corticomotoros pályákban $[8,16]$.

- Pozitronemissziós tomográfiás (PET) felvételek csökkent glükózmetabolizmust mutatnak a cerebellumban, fokozott anyagcserét a pallidumban [8].

- AzATM-gén vizsgálata: biallélikus patogén mutáció(k) kimutatása: először szekvenálás javasolt, ennek negativitása esetén végzendő el a deletiók, illetve duplikációk analízise. Egyes populációkban (például amis, szardíniai, észak-afrikai zsidó) érdemes elsóként a csoportra jellemző founder mutációt vizsgálni. Az ATM-gén vizsgálata elvégezhető új generációs szekvenálással (NGS), multigén panel részeként. E panelek tartalma és szenzitivitása az őket összeállító laboratóriumoktól függ $[7,8]$. A beteg mutációjának ismerete lehetőséget nyújt a következő terhesség során intrauterin magzati diagnosztika elvégzésére, a terhesség sorsáról való felelősségteljes szülői döntéshozatalra, és alapfeltétele egy esetleges génterápiának.

- ATM-fehérje kimutatása (immunoblottal, lymphoblastoid sejtvonalon) a bizonytalan jelentőségű ATMvariánsok értelmezésében segíthet. Az AT-betegek 90\%-ában hiányzik, 10\%-ukban nyomokban mutatható ki, az esetek töredékében pedig normális mennyiségű, de hiányzik a szerin/treonin kináz aktivitása ( „kinase-dead" protein) [7].

Differenciáldiagnosztika: erősen megkérdőjelezhető az AT, ha súlyos kognitív deficit, epilepsziás görcsök kísérik, ha az ataxia nem progresszív, illetve ha a beteg microcephaliás [7]. A klinikai kép függvényében a következő betegségek lehetősége mérlegelendő:

- Infantilis cerebralis paresis, mely nem progresszív, nem jár teleangiectasiákkal, és gyakori a spasticitas, a súlyos kognitív deficit.

- Congenitalis oculomotor apraxia.

- Friedreich-ataxia.
- Microcephalia, görcsök, vontatott fejlödés (MCSZ): korai görcsökkel, microcephaliával jár, és ugyancsak DNS-repair-zavar. Ionizáló sugárzásra való fokozott érzékenység jellemzi, a PNKP-gén biallélikus mutációi okozzák [7].

- Emelkedett AFP-vel járnak az alábbi betegségek: ataxia-oculomotoros apraxia 2-es tipusa (AOA2), RNF168-deficientia [17].

- 7;14 kromoszómatranszlokációkkal-melyek radioszenzitivitáshoz, DNS-repair-zavarhoz, immundeficientiához és fokozott tumorrizikóhoz vezetnek (XCIND: $\mathrm{X}$-ray sensitivity, cancer, immunodeficiency, neuropathology, DNA repair deficiency) - járnak az alábbi betegségek:

- Nijmegen-törés-szindróma (NBS): microcephalia, súlyos kognitív deficit, de nincs se ataxia, se teleangiectasia [18].

- Ataxia teleangiectasia-szerü betegség (ATLD): az MRE1 l-gén biallélikus mutációi okozzák. Progresszív cerebellaris ataxia, oculomotoros apraxia, radioszenzitivitás jellemző, de a progresszió lassúbb, és az AFP normális, teleangiectasia, immundeficientia nincs [19].

- RAD50-deficientia: alacsonynövés, nem progresszív ataxia, igen ritka.

- RNF168-deficientia: igen ritka. Ataxia, ocularis teleangiectasia, progresszív restriktív légzési elégtelenség, alacsonynövés, microcephalia, tanulási zavar, emelkedett AFP, arcdysmorphia jellemzi, az intelligencia normális lehet [17].

- Ataxia-oculomotoros apraxia 1-es tipusa (AOA1).

- Autoszomális recessziv spinocerebellaris ataxia 9-es tipusa koenzim-Q-hiánnyal [20].

- Csecsemökori kezdetü spinocerebellaris ataxia (IOSCA): biallélikus TWNK-gén-mutáció okozza.

- Szenzoros ataxiás neuropathia dysarthriával és ophthalmoplegiával (SANDO): a POLG-gén biallélikus patogénvariánsai okozzák.

- X-bez kötött sideroblastos anaemia ataxiával: az ABCB7-gén mutációi okozzák. 


\section{Kezelés, gondozás}

A kezelés döntően tüneti, szupportív: gyógytorna, foglalkozás-, beszédterápia, a kontraktúrák és a scoliosis megelőzése ortézisekkel, a nyálzás csökkentése. Mindezek segítenek a funkciók megőrzésében, de nem lassítják a neurodegenerációt. A táplálkozási zavar okozta cachexia elkerülésére időben beültetett gastrostomára (PEG) lehet szükség.

Gyógyszeresen a domináló mozgászavar függvényében megkísérelhetők trihexifenidil, amantadin, baklofen, botulinustoxin, ritkábban klonazepám, gabapentin, pregabalin [8], de az ezekre adott válasz egyedi, kiszámíthatatlan [7].

Szteroidok (dexametazon és betametazon) időlegesen, a kezelés időtartamára javítják a neurológiai tüneteket, de fóleg a tünetszegényebb, fiatalabb gyermekekben hatékonyak. A kezelés leépítése a funkciók romlását vonja maga után [21].

Fontos személyre szabott oltási terv mentén a fertőzések elleni védekezés, súlyos hypogammaglobulinaemia esetén a gamma-globulin pótlása [8].

A légzésfunkciót, a tüdó állapotát 6 éves kortól évente ellenőrizni kell. Makacs légúti tünetek esetén CT/MR vizsgálattal kell tisztázni a háttérben álló bronchiectasiát, fibrosist, interstitialis tüdőbetegséget (ILD), esetleg tumort. Az ILD általában jól reagál szteroidra [8].

Malignus kórfolyamat esetén különös gondot kell fordítani az ionizáló besugárzás, illetve a radiomimetikus kemoterápiás szerek elkerülésére, ha ez nem lehetséges, legalább dózisuk minimalizálása, az intervallumok növelése javasolt [22].

Az AT-betegek anesztéziája is több veszéllyel jár, ezért csak gyakorlott, tapasztalt, ebben jártas orvos végezze [7].

További terápiás próbálkozások folynak antioxidánsokkal, melyek közül az alfa-liponsav ígéretes lehet, mert átmegy a vér-agy gáton, és javítja a mitokondriális funkciót. Aminoglikozidok kis mennyiségben segítik a teljes hosszúságú fehérje képződését. Hasonló a célja más 'readthrough' (a károsodott DNS-szakaszt áthidaló) szereknek, például az amlexanoxnak, melyet nonsense patogénvariánsok esetén tesztelnek. Az antisense morpholino oligonukleotidok (AMO) bizonyos 'splice' variánsokban lehetnek hatásosak. Klinikai vizsgálat folyik inzulinszerú növekedési faktorral, valamint a radioprotektív hatású szuperoxid-dizmutáz-szerü anyagokkal.

\section{Prognózis}

Az AT-betegek korábban gyermek- vagy serdülőkorban meghaltak, a jobb gondozás és eddig ismeretlen egyéb okok miatt a várható élettartam nő: ma a legtöbb beteg 25 évnél tovább él, de van példa 50 évesnél magasabb életkorra is [23]. A leggyakoribb halálokok a malignus folyamatok, illetve a krónikus tüdőbetegség.
Újszülöttkori szürés: a súlyos kombinált immundefektusokra kidolgozott szúrővizsgálat aspecifikusan, de detektálja az AT-betegeknek azt a mintegy 50\%-át, akikben lymphopenia van jelen [7]; a még tünetmentes betegek pontos diagnózisához ilyenkor a teljesexom-szekvenálás (WES) vezethet el [8]. A hatékony szürésnek és kórismézésnek a családtervezés szempontjából van kiemelt jelentősége, de ez a későbbiekben, specifikus terápiás lehetőség(ek) birtokában, további fontos szerepet nyerhet.

\section{Következtetés}

A veleszületett immundefektusok jelentős része jár neurológiai tünetekkel, melyek az ideg-izom rendszer különböző funkcionális rendszereit érinthetik. Még több az olyan primer immundeficientia, melyben az immunhiány a központi idegrendszert (is) érintő súlyos infekcióhoz vezet. Klasszikus, komplex központi idegrendszeri kórkép a részletesen ismertetett ataxia teleangiectasia, melyben a kötelező mozgászavar(ok) és tanulási nehézségek mellett igen gyakori az immunhiány, a fokozott hajlam malignus kórfolyamatokra és infekciókra, a tüdő destruktív megbetegedésére. A kezelés lehetőségei jelenleg korlátozottak.

Csakúgy, mint minden primer immundeficientiában, a korai diagnózis lehetővé teszi a további gyermekvállalás rizikójának megbecsülését, valamint az intrauterin diagnosztikát.

Anyagi támogatás: A szerző a közlemény megírásáért anyagi támogatásban nem részesült.

A szerző a cikk végleges változatát elolvasta és jóváhagyta.

Érdekeltségek: A szerzőnek nincsenek érdekeltségei.

\section{Irodalom}

[1] Maródi L. Editor's commentary. Interdisciplinary immunodeficiency: a novel approach to understanding primary immunodeficiency disorders. [Interdiszciplináris immundeficientia: új szemlélet a primer immunhiány-betegségek értelmezésében.] Orv Hetil. 2018; 159: 895-897. [Hungarian]

[2] Bousfiha A, Jeddane L, Picard C, et al. The 2017 IUIS phenotypic classification for primary immunodeficiencies. J Clin Immunol. 2018; 38: 129-143. [Epub 2017 Dec 11]

[3] Zhang S, Pondarre C, Pennarun G, et al. A nonsense mutation in the DNA repair factor Hebo causes mild bone marrow failure and microcephaly. J Exp Med. 2016; 213: 1011-1028.

[4] Flinn AM, Gennery AR. Adenosine deaminase deficiency: a review. Orphanet J Rare Dis. 2018; 13: 65.

[5] Wu X, Wu W, Pan W, et al. Acute necrotizing encephalopathy: an underrecognized clinicoradiologic disorder. Mediators Inflamm. 2015; 2015: 792578.

[6] Crow YJ, Manel N. Aicardi-Goutières syndrome and the type I interferonopathies. Nat Rev Immunol. 2015; 15: 429-440. 
[7] Gatti R, Perlman S. Ataxia-telangiectasia. In: Adam MP, Ardinger HH, Pagon RA, et al. (eds.) SourceGeneReviews ${ }^{\circledR}$ [Internet]. University of Washington, Seattle, WA, 1993-2018. 1999 Mar 19 [updated 2016 Oct 27]

[8] Rothblum-Oviatt C, Wright J, Lefton-Greif MA, et al. Ataxia telangiectasia: a review. Orphanet J Rare Dis. 2016; 11: 159

[9] Nowak-Wegrzyn A, Crawford TO, Winkelstein JA, et al. Immunodeficiency and infections in ataxia-telangiectasia. J Pediatr. 2004; 144: 505-511.

[10] Chun HH, Gatti RA. Ataxia-telangiectasia, an evolving phenotype. DNA Repair (Amst.) 2004; 3: 1187-1196.

[11] Verhagen MM, Abdo WF, Willemsen MA, et al. Clinical spectrum of ataxia-telangiectasia in adulthood. Neurology 2009; 73: $430-437$.

[12] Charlesworth G, Mohire MD, Schneider SA, et al. Ataxia telangiectasia presenting as dopa-responsive cervical dystonia. Neurology 2013; 81: 1148-1151.

[13] Hiel JA, van Engelen BG, Weemaes CM, et al. Distal spinal muscular atrophy as a major feature in adult-onset ataxia telangiectasia. Neurology 2006; 67: 346-349.

[14] Byrd PJ, Srinivasan V, Last JI, et al. Severe reaction to radiotherapy for breast cancer as the presenting feature of ataxia telangiectasia. Br J Cancer 2012; 106: 262-268.

[15] van Os NJ, Roeleveld N, Weemaes CM, et al. Health risks for ataxia-telangiectasia mutated heterozygotes: a systematic review, meta-analysis and evidence-based guideline. Clin Genet. 2016; 90: 105-117.
[16] Habek M, Brinar VV, Rados M, et al. Brain MRI abnormalities in ataxia-telangiectasia. Neurologist 2008; 14: 192-195.

[17] Devgan SS, Sanal O, Doil C. Homozygous deficiency of ubiquitin-ligase ring-finger protein RNF168 mimics the radiosensitivity syndrome of ataxia-telangiectasia. Cell Death Differ. 2011; 18: $1500-1506$

[18] Chrzanowska KH, Gregorek H, Dembowska-Bagińska B, et al. Nijmegen breakage syndrome (NBS). Orphanet J Rare Dis. 2012; 7: 13 .

[19] Federighi P, Ramat S, Rosini F, et al. Characteristic eye movements in ataxia-telangiectasia-like disorder: an explanatory hypothesis. Front Neurol. 2017; 8: 596.

[20] Lagier-Tourenne C, Tazir M, López LC, et al. ADKC3, an ancestral kinase, is mutated in a form of recessive ataxia associated with coenzyme Q deficiency. Am J Hum Genet. 2008; 82: 661672 .

[21] Gatti RA, Perlman S. A proposed bailout for A-T patients? Eur J Neurol. 2009; 16: 653-655.

[22] Schütte P, Möricke A, Zimmermann M, et al. Preexisting conditions in pediatric ALL patients: spectrum, frequency and clinical impact. Eur J Med Genet. 2016; 59: 143-151.

[23] Crawford TO, Skolasky RL, Fernandez R, et al. Survival probability in ataxia telangiectasia. Arch Dis Child. 2006; 91: 610611.

(Liptai Zoltán dr., Budapest, Albert Flórián út 5-7., 1097 e-mail: zliptai@dpckorhaz.hu)

\section{Felhívás előfizetésre}

Legyen Olvasónk a következő évben is!

Fizessen elő az Orvosi Hetilap 2019-es évfolyamára!

Egy füzet ára: $1150 \mathrm{Ft}$.

Éves előfizetési dij: $49900 \mathrm{Ft}$, nyugdijasoknak: $39990 \mathrm{Ft}$.

Az online változat éves előfizetési dija: $29990 \mathrm{Ft}$. 